\title{
INTERATIVIDADE DIGITAL, AUDIÊNCIA E WEBDOCUMENTÁRIOS
}

\author{
Paulo Eduardo Cajazeira; José Jullian Gomes de Souza*
}

Resumo: O presente texto pertence a uma investigação em que busca-se a compreensão da interatividade e da audiência, tendo como ponto de partida o desenvolvimento de novos produtos audiovisuais jornalísticos. Os webdocumentários procuram em sua estrutura uma nova tendência mais participativa, e sendo assim, analisar e compreender este conteúdo na Web possibilita adentrar neste novo cenário advindo com a convergência digital das mídias.

Palavras-chave: Interatividade; webséries documentais; INFOtenimento; audiovisual; convergência

Resumen: Este texto pertenece a una investigación que pretende entender la interactividad y la audiencia, tomando como punto de partida el desarrollo de nuevos productos audiovisuales periodísticos. Los webdocumentales buscan en su estructura una nueva tendencia más participativa, y, por ello, analizar y comprender este contenido en la Web permite adentrarse en este nuevo escenario surgido con la convergencia digital de los medios.

Palabras clave: interactividad, webseries documentales, INFOtenimiento, audiovisual, convergencia.

Abstract: This text is part of an investigation that seeks to understand the interactivity and the audience, taking as a starting point the development of new journalistic audiovisual products. The webdocumentaies seek in its structure a more participatory trend. If so, to analyze and understand this content on the Web enables us to enter in a new scenario that has been arising with digital media convergence.

Keywords: interactivity, documentary webseries, INFOtainment, audiovisual convergence.

Résumé: Ce texte appartient à une enquête qui cherche à comprendre l'interactivité et le public, en prenant comme point de départ le développement de nouveaux produits audiovisuels journalistiques. Les webdocumentários cherchent dans sa structure une nouvelle tendance plus participative, et s'il en va ainsi, analyser et comprendre ce

\footnotetext{
* Paulo Eduardo Cajazeira: Doutor em Comunicação e Semiótica (PUC-SP), Pós-doutor em Ciências da Comunicação - UBI/Portugal. Professor do Curso de Jornalismo do Instituto Interdisciplinar de Sociedade, Cultura e Arte da Universidade Federal do Cariri, Brasil. Grupo de Pesquisa: Centro de Estudos e Pesquisa em Jornalismo (UFCA, CNPq, Brasil). 63048-080, Juazeiro do Norte, Brasil. E-mail: paulo.cajazeira@ufca.edu.br

José Jullian Gomes de Souza: José Jullian Gomes de Souza: Graduando em Jornalismo, Curso de Jornalismo do Instituto Interdisciplinar de Sociedade, Cultura e Arte da Universidade Federal do Cariri, Brasil; Grupo de Pesquisa:Centro de Estudos e Pesquisa em Jornalismo (CEPEJor, UFCA, CNPq). 63048-080, Juazeiro do Norte, Brasil.

E-mail: jullianjose64@gmail.com
}

Submissão do artigo: 30 de maio de 2015. Notificação de aceitação: 03 de setembro de 2015. 
contenu sur le Web permettrait de pénétrer ce nouveau scénario résultant de la convergence des médias numériques.

Mots-clés: interactivité, websérie documentaire, INFOdivertissement, la convergence de l'audiovisuel.

\section{Introdução}

Com o desenvolvimento das novas tecnologias da informação e da comunicação, novos formatos audiovisuais surgem como um modelo de apropriação e forma de permear toda a superfície dessas produções, em paralelo com os novos meios de comunicação. O advento da Internet, no campo da informação e entretenimento, possibilitou diversas inovações tecnológicas, que propiciaram a criação e o desenvolvimento de um novo seguimento no campo audiovisual: os webdocumentários ou webséries documentais. A fórmula conhecida de narratividade do documentário mais a junção das ferramentas da Web permitiram a hibridação entre o tradicional e contemporâneo, e assim, tornou-se possível visualizarmos a produção de um conteúdo audiovisual que ultrapassou as barreiras do cinema, da televisão e adentrou à Internet com características específicas: a narrativa hipertextual, multimídia e a interatividade permanente com o usuário.

A interatividade e a interação são conceitos importantes e que vem sendo muito explorados e discutidos por teóricos ao longo dos anos, nos estudos em comunicação. Na Era Digital essa relação é indispensável para que possamos compreender como se relacionam com a audiência. Alex Primo (2007: 19) na obra “A interação mediada por computador" traz um panorama sobre essa relação de interatividade e interação que está sendo difusa no meio digital, pois "o desenvolvimento dos meios de comunicação veio oferecer novos formatos de ação e novos tipos de relacionamento sociais". 
A interatividade, em conjunto com o hipertexto, a multimídia e a instantaneidade na convergência digital transformam não apenas a produção audiovisual disponibilizada na Internet, mas na própria apropriação dos novos conteúdos por usuários ou web- espectadores, como define Guto Aeraphe (2013: 11). Esses webespectadores assistem a uma crescente modificação nos formatos audiovisuais, com a expansão da Web. A pesquisadora Raquel RitterLonghi (2014: 70) explica que os formatos noticiosos no Ciberjornalismo estão em renovação constante, o que desafia classificações tradicionais estabelecidas. Isso nos possibilita a denominar ou classificar essa nova produção como uma websérie documental, com características próprias e impactadas pelo elemento da interatividade, que se situa na reflexão atual da Internet e dos meios de comunicação em convergência.

O webdocumentário, nas palavras de Oliver Crou (2010: 18), é um documentário cuja concepção e realização são feitas para a Web e por ela difundida. O modo de narração dos webdocumentários é concebido de maneira que o leitor/espectador navegue pela interface de forma totalmente delinearizada. É ele quem conceberá de maneira única seu percurso no webdocumentário. São esses percursos que denominamos de hipertextualidade que visamos delinear nessas novas produções e que trataremos aqui como webséries documentais. Desconstruir as peças para que possamos entendê-la isolada e conjuntamente, a fim de perceber como as webséries documentais são apropriadas pelo jornalismo e se utilizam dessa narrativa hipertextual, multimídia e interativa como meio de alavancar a sua audiência e atingir novos públicos nesse novo cenário midiático.

Inicialmente com um caráter de entretenimento, as webséries buscavam estabelecer não apenas uma nova linguagem, mas outra relação de produção, consumo, circulação e interação com o espectador que se encontra no ambiente virtual, e que não se encaixa no padrão de receptor passivo que recebe o conteúdo sem algum questionamento, como as mídias 
tradicionais o percebem. Contendo características próprias de funcionalidade, como narrativa, formato, duração de episódio e ambiente de circulação, as webséries provocam uma reflexão sobre o futuro que o audiovisual percorrerá nos próximos anos, principalmente no campo das ciências da comunicação e em sua abertura nos novos formatos jornalísticos.

O processo de interação entre o conteúdo das webséries e os espectadores, surge com a proposta de narrativa transmídia, com a centralização da figura do computador mediando a interação entre o universo digital e os usuários desse novo meio de comunicação. Produtores e espectadores passam a ter um funcionamento diferenciado, uma vez que o receptor - considerado por muito tempo como passivo - passou a intervir e a reivindicar uma maior participação e interação como destaca Henry Jenkins (2009: 32) já que a circulação do conteúdo na Web, hoje, depende fortemente de uma participação ativa. Esse paradigma da convergência, que modifica a percepção dos formatos jornalísticos, da interação com os novos meios e, principalmente, do papel que o espectador possui na mídia atual, tem sido utilizado pelo jornalismo como uma das tendências em produzir novos conteúdos mais dinâmicos e interativos para esse público.

As webséries tinham em sua criação inicial um viés fortemente de entretenimento, e com a apropriação jornalística passam por uma (re) configuração com a convergência e que se desenvolve o webdocumentário (ou websérie documental, como pretendo denominar). Há uma discussão no campo acadêmico sobre a conceituação e denominação desses novos formatos oriundos com à Internet, e que devido a "variedade de estilos e formatos desses projetos não facilita a tentativa de conceituar o que é um webdocumentário" (Bauer, 2011: 91).

Não apenas os conceitos acima remodelam a produção desse novo conteúdo audiovisual elaborado especificamente para a Web, mas também a relação entre informação (jornalismo) e diversão (entretenimento) que estes 
produtos possuem. Sob o conceito de INFOtenimento e interatividade, as webséries documentais perpassam a atual fase dos documentários, e nos coloca em uma posição defronte as inovações audiovisuais no campo da comunicação que buscaremos compreender nesse cenário emergente de múltiplos produtos digitais e na sua relação estabelecida com o espectador na análise exploratória e de conteúdo, tendo como base o aspecto da audiência.

\section{Revisitando os aspectos teóricos do estudo}

Alejandro Rost (2014: 52) discute a interatividade como sendo um dos conceitos chaves para o jornalismo em época de convergência das mídias. O autor compreende a interatividade para além do jornalismo online, mas como algo que está presente no cotidiano dos jornalistas e da sociedade do século XXI:“A interatividade é um conceito ponte entre o meio e os leitores/utilizadores, porque permite abordar esse espaço de relação entre ambas as partes e analisar as diferentes instâncias de seleção, intervenção e participação nos conteúdos do meio" (Jost, 2014: 53). Essa proposta de interatividade vem acompanhada, principalmente, por outros três conceitos: a hipertextualidade, instantaneidade e a multimedialidade.

Na coletânea de textos organizada pelo pesquisador João Canavilhas (2014: 1-2) com a colaboração de diversos autores sobre determinadas características do webjornalismo, três foram discutidas e problematizadas por João Canavilhas (a hipertextualidade), Paul Bradshaw (a instantaneidade) e Ramón Salaverría (a multimedialidade). Esses conceitos nos ajudam a compreender o universo complexo desses novos fenômenos audiovisuais das webséries documentais. Por hipertextualidade, Canavilhas (2014: 3) explica as novas arquiteturas noticiosas da Web, a partir de três fatores: os históricos, técnicos e econômicos. A hipertextualidade possui papel central no processo de interatividade entre o conteúdo jornalístico e o 
espectador que se encontra na Internet. $\mathrm{O}$ webjornalismo fundamenta-se na utilização do hipertexto criando uma nova narrativa não sequencial e permitindo que o webespectador crie sua própria narrativa, a partir das possibilidades de navegação.

A instantaneidade é outro fator que vem sendo difundido na rede e impactando no modo das produções audiovisuais jornalísticas para a Web. As webséries documentais possuem em sua estrutura esse caráter instantâneo, que é explicado por Paul Bradsahw (2014: 111) como relativo a velocidade intrínseca ao jornalismo digital e que denomina como imediaticidade da informação. E que carrega consigo as questões relacionadas a chegada da nova mídia e dos novos suportes. A propagação e $\mathrm{o}$ alcance que possuem modificam o consumo e a redistribuição do produto audiovisual na era da Internet. A instantaneidade funciona como um processo inerente da digitalização que o pesquisador Marcos José Pereira (2011: 58) descreve como sendo a partir da informatização dos sistemas e que a comunicação perpassa essas novas formas de trabalho, e passa a funcionar com uma maior rapidez na transmissão de informação.

A informatização do sistema foi um processo fundamental para que o computador se tornasse definitivamente uma ferramenta de interação trabalhando com as várias mídias integradas e os recursos, como imagens, sons, vídeos e filmes interagindo dinamicamente, como explica Pereira (2011: 59). Essa interação nos leva diretamente ao conceito de sistema multimídia, entendido pelo autor como a possibilidade de manipulação dessas mídias no ambiente digital, propiciado pelo computador.

O pesquisador Ramón Salaverría (2014: 25) trata da multimídia analisando-a em um contexto histórico e como a sua evolução processa-se na contemporaneidade. Essa combinação de sons, textos e imagens explicada por Pereira (2011: 59) é compreendida por Salaverría (2014: 29) como uma definição que não dá conta da complexidade do conceito de 
multimídia, pois seria um reducionismo das possibilidades inerente a esse novo sistema.

A multimídia encontra-se ancorada, em nossa sociedade, principalmente com a revolução da Era da Convergência e da Web 2.0. A Internet entra em despontamento nas últimas décadas do século XXI, num cenário predominantemente marcado pelo fenômeno televisivo. A Web, como é denominada pela maioria dos usuários e pesquisadores, perpassa diversos estágios e (re) configuração de suas funções, criações, desenvolvimentos e potencialidades desse novo meio de comunicação que transpassa fronteiras, e que foi denominada de Web 2.0. Aglomerando as multiplataformas, as possibilidades permitidas a partir de cada um dos meios de comunicação tradicional e unificando-as em um único meio difusor, o digital, a Web 2.0 integra um sistema em conjunto com a cultura da convergência.

Com o advento da difusão da Internet e da Web 2.0 em larga escala na sociedade contemporânea, novos conceitos, nomenclaturas e modos de organização, no universo da comunicação, são fundamentados para que seja possível abarcar uma infinidade de transformações e movimentos em torno da cultura digital. Problematizando as questões pertinentes aos novos conteúdos, as empresas de comunicação, na relação entre produtores e consumidores e formatos midiáticos é um dos problemas pesquisado por Henry Jenkins (2009: 30) que traz em seu livro "Cultura da Convergência" um panorama atual sobre o status dos meios de comunicação tradicionais em diálogo com a revolução advinda do meio de comunicação digital e os novos consumidores.

"Bem-vindo à cultura da convergência, onde as velhas e as novas mídias colidem, onde mídia corporativa e mídia alternativa se cruzam, onde o poder do produtor de mídia e o poder do consumidor interagem de maneiras imprevisíveis" (Jenkins, 2009: 29). Assim, somos apresentados ao mundo convergente que o autor descreve em sua obra e que define como: 
Um fluxo de conteúdos através de múltiplas plataformas de mídia, à cooperação entre múltiplos mercados midiáticos e ao comportamento migratório dos públicos dos meios de comunicação, que vão a quase qualquer parte em busca das experiências de entretenimento que desejam (Jenkins, 2009: 29).

Não sendo um conceito tão recente, a convergência foi discutida por Ithiel de Sola Pool, um dos profetas dos meios de comunicação, e em seu livro "Technologies of freedom" (1983). O autor foi um dos primeiros a delinear o conceito de convergência. Mas foi a partir da discussão permeada por Henry Jenkins, que o conceito tomou as suas devidas proporções e problematizações que se encontram no cenário atual do jornalismo, entretenimento e produções audiovisuais no ciberespaço.

Com o surgimento dos novos meios de comunicação criou-se uma expectativa sobre o fim dos antigos meios. Porém, o que se observa é uma integração entre esses diferentes meios midiáticos, em que de um lado temos a manutenção dos antigos meios, e de outro, as novas possibilidades de produção e circulação de conteúdos fragmentados e dispersos na Internet baseado na interatividade. Na era da convergência:

As fusões multimídia e as concentrações de empresas na produção de cultura correspondem, no consumo cultural, à integração de rádio, televisão, música, notícias, livros, revistas e Internet. As fusões multimídia e as concentrações de empresas na produção de cultura correspondem, no consumo cultural, à integração de rádio, televisão, música, notícias, livros, revistas e Internet. (Canclini, 2008: 33).

Essa interação e integração entre as velhas e novas mídias estão modificando não somente o olhar das grandes empresas de comunicação e da produção de conteúdo para a plataforma digital, mas, principalmente, o olhar do espectador/usuário que adquire um novo status com a introdução dessas tecnologias e da convergência das mídias. O espectador passa, neste 
atual momento, a compor um dos elementos indispensáveis para o entendimento mercadológico e participativo da comunicação. A inserção do espectador com uma lógica mais participativa é um dos principais fatores que alteraram a sociedade tecnológica contemporânea. Mas é importante esclarecer é que os meios de comunicação não estão sendo substituídos, mas suas funções estão se transformando, uma vez que:

A convergência das mídias é mais do que apenas uma mudança tecnológica. A convergência altera a relação entre tecnologias existentes, indústrias, mercados, gêneros e públicos. A convergência altera a lógica pela qual a indústria midiática opera e pela qual os consumidores processam a notícia e o entretenimento. (Jenkins, 2009: 43).

A convergência é vista como um processo, um impacto profundo no modo como a sociedade consome e como as empresas produzem os conteúdos para os meios de comunicação. Ela pode ocorrer de várias maneiras, mas a principal como explica Jenkins (2009: 45) é na tomada de controle das mídias pelos consumidores. A ideia de controle pelos consumidores decorre da apropriação que estes atores têm de uma conscientização do seu papel nessa reconfiguração das mídias. O sentimento de coletividade, expresso na ideia de Pierre Lévy (2014: 29) da inteligência coletiva, em que o saber fragmentado entre os participantes de uma comunidade é compartilhado e distribuído entre os seus membros, como uma forma de fazer emergir essa cultura mais participativa visualizada por Jenkins, afinal, “a expressão cultura participativa contrasta com noções mais antigas sobre a passividade dos espectadores dos meios de comunicação" (Jenkins, 2009: 30).

$\mathrm{Na}$ cultura da convergência, a interatividade é uma palavra-chave para que seja possível compreender os novos paradigmas que a sociedade digital tem sido constantemente transformada. As produções em audiovisual encontram-se em um momento de renovação com a difusão das ferramentas 
de produção, edição e participação do espectador/usuário. Se a televisão adaptou o audiovisual para o seu suporte advindo do modelo cinematográfico, na era da Internet, essas produções são desafiadas a incorporaram-se em meio a uma infinidade de variações de formatos.

A narrativa consolidada pelo cinema e pela televisão busca adaptarse para as telas da Web, sob as novas diretrizes ditadas pela convergência e pela cultura participativa numa época marcada pelo hibridismo. Essa nova audiovisualidade que está imergindo é, segundo a pesquisadora Miriam Rossini (2009: 14), uma hibridação entre o cinema e a televisão que não se dá, agora, com o tempo atual, mas foi uma construção ao longo do tempo. Uma construção que passou por uma série de processos e permeou a mídia digital com sua forte hipertextualidade em uma narrativa transmídia. E, sendo assim, o estudo dessa apropriação se faz necessário para que seja possível a compreensão da nova produção audiovisual jornalística (a websérie documental) na perspectiva dos conceitos acima e agregando-se a ele o conceito de INFOtenimento nesse produto audiovisual digital.

Essa audiovisualidade tem sido percebida pelas corporações jornalísticas e utilizadas para atrair novos públicos e novos formatos noticiosos, com a interrelação entre informação e entretenimento explicada por Dejavite (2006: 71) como INFOtenimento: um jornalismo que ao mesmo tempo traz uma prestação de serviço e propicia aos leitores informação com entretenimento. O INFOtenimento é o espaço destinado às matérias que visam informar e divertir como, por exemplo, os assuntos sobre estilo de vida, as fofocas e as notícias de interesse humano - os quais atraem, sim, o público. Mas na sua aplicação as webséries, o conceito de INFOtenimento colabora para que a proposta de uma narrativa hipertextual e interativa se torne o ponto de discussão entre o jornalismo e o entretenimento na era da convergência.

O termo INFOtenimento surgiu na década de 1980, quando acadêmicos da área da comunicação, passam a refletir sobre a prestação de 
serviço e ao mesmo tempo que oferece divertimento ao consumidor. Deuze (2001: 12) explica que o conceito de INFOtenimento no jornalismo está dividido em duas categorias: [1] no aumento de elementos de entretenimento em gêneros de notícias informativas e [2] na elevação e no estabelecimento de gêneros de INFOtenimento existentes atualmente. É nesse segundo ponto que trazemos a problematização das webséries documentais: a sua relação entre informação e entretenimento a partir dessa linguagem hipertextual e transmidiática. E que buscaremos compreender como essa classificação se encontra na contemporaneidade dialogando com a websérie documental e o seu conteúdo.

A audiência, em termos gerais é a medição da satisfação do público em relação, por exemplo, a um programa de TV, um filme, um jogo ou a algo que se relaciona com o hábito de consumo, principalmente midiático. O pesquisador Daniel Dayan (2006: 45) explica que a audiência se encontra em uma posição complexa, pois o caráter da audiência reside no que resta do público após o seu estabelecimento. Em linhas gerais é possível afirmar que o público representa um meio, e esse meio poderá determinar o nível de audiência que determinado produto terá ou não, como ocorre no caso das webséries, em que o público virtual será o balizamento para a sua medição.

A relação entre o público e audiência é uma relação instável e passiva de movimentações a todo o instante. Com essas novas transformações que acompanhamos e com o crescente aumento das mídias e suas ferramentas de alcance, a audiência enfrenta modificações em sua estrutura. A pesquisadora Carla Pollake da Silva (2006: 12) ao estudar sobre audiência e recepção visa compreender como a passagem do consumidor passivo para ativo implica, diretamente, no modelo de audiência. A autora explica que já com as primeiras manifestações de mobilização das multidões no início do século XX, com a utilização da propaganda, os estudos de audiência começam a ser formados na sociedade. 
A audiência não se caracteriza por essa personificação e nem por uma obrigação de ser sociável e estável. A sua atuação responde a uma solicitação. Tal qual o público, a audiência se instala em uma realidade imaginada (Cajazeira, 2014: 21). O pesquisador e professor Paulo Eduardo Cajazeira retrata com a fala acima que a audiência tende a ser uma realidade imaginada, pois ela tem um caráter simbólico na relação entre produtores e consumidores, e na era da convergência essa relação perpassa novos desafios de medição.

A audiência com o advento das tecnologias, das redes sociais digitais e da maior interatividade entre produtores e consumidores de conteúdos não está baseada mais apenas em números de ibope. Outros formatos e formas são considerados para a compreensão dessa nova audiência como, por exemplo, o número de visualizações, os inúmeros comentários deixados nas páginas, a número de compartilhamento, curtidas e etc. A reconfiguração da audiência perpassa os próprios moldes de produção, circulação e difusão do conteúdo da era digital.

Uma descentralização da audiência começa a ser percebida pelas empresas de comunicação com a chegada do aparato digital. E com isso requer que novos processos sejam analisados, aferidos e compreendidos diante essa nova sociedade que busca uma maior participação em conjunto com a produção noticiosa.

\section{Metodologia}

Para analisar e compreender como o fenômeno das webséries documentais se encontra no campo digital, um estudo de caso a partir da pesquisa exploratória e da análise de conteúdo nos permite um maior detalhamento das acepções e conceitos pré-estabelecidos no conteúdo das webséries documentais. A relação de interatividade e a participação do espectador a partir de uma navegação interativa, e que permeia 
possibilidades e experiências diferenciadas é sentida na webséries "A short historyofthehighrise" (2013). A websérie documental elaborada pelo NYTimes.com sob a proposta de interação a partir dos toques, pois visa dialogar diretamente com as novas possibilidades advindas com o avanço da tecnologia, principalmente para o campo jornalístico.

A pesquisa exploratória permite uma aproximação mais intimista entre o pesquisador e o tema pesquisado, visto que o tema ainda é pouco explorado e conhecido, como no caso das webséries documentais em que poucas pesquisas existem sobre o assunto, principalmente no Brasil. Nesse sentido, a problemática não se apresenta com aspectos que permitam uma visualização dos procedimentos, e se faz necessário que o pesquisador inicie um processo de sondagem, de varredura para o aprimoramento das ideias, e, posteriormente, da construção de suas hipóteses.

Em consonância com a análise de conteúdo de Laurence Bardin (1977: 29) que "é uma proposta em reação à análise subjetiva de textos, e envolve uma necessidade de sistematização impostas pelo próprio desenvolvimento do processo" (Temer, 2014: 36). Compreendemos esse tipo de análise para a medição do tipo de conteúdo com finalidades descritivas, sistemáticas e quantitativas e que se adaptou para uma metodologia de análise das tecnologias digitais. A análise de conteúdo possui duas funções: 1) função heurística: a análise de conteúdo enriquece a tentativa exploratória, aumenta a propensão à descoberta. É a análise de conteúdo <para ver o que dá>; e uma 2) função de <administração da prova>: hipóteses sob a forma de questões ou de afirmações provisórias servindo de diretrizes, apelarão para o método de análise sistemática para serem verificadas no sentido de uma confirmação ou de informação.

$\mathrm{Na}$ análise de conteúdo não existe o "pronto", mas uma base norteadora. "O conteúdo é marcado por uma grande disparidade de formas e

${ }^{1}$ A short history oh the Highrise - websérie documental produzida pelo NYTimes.com. Disponível em: http://www.nytimes.com/projects/2013/high-rise/. 
adaptável a um campo de aplicação vasto a comunicação" (Bardin, 1977: 31). Ela pode ser aplicada a uma descrição do conteúdo das mensagens, já que a palavra é o conteúdo a ser analisado em sua metodologia. Uma análise detalhada e rigorosa que aplicada ao conteúdo interativo das webséries documentais, nos possibilitará a compreensão da ascensão desse modelo de produção e da emergência desse novo espectador que está na rede, na Web: o webespectador.

O usuário adere à participação dos formatos audiovisuais que se encontram nesse novo espaço midiático e participa dessa nova discussão que permite um retorno mais rápido sobre essa produção digital e interativa. A participação no ambiente digital é de extrema importância para que possamos compreender como o diálogo está sendo estabelecido entre o conteúdo e o espectador, e como esse participa do processo interativo possibilitado pelas webséries documentais, uma vez que as tecnologias estão avançando e que estamos inseridos nessa conjuntura. Sendo assim, em conjunto com a metodologia exploratória, utilizaremos a método qualitativo no estudo de caso, um tipo que se refere a esse tipo de metodologia mais específica da análise de conteúdo.

“A pesquisa qualitativa não se preocupa com representatividade numérica, mas sim como o aprofundamento da compreensão de um grupo social" (Gerhard; Silveira, 2009: 31). Esse grupo social, aplicado a nossa pesquisa se encontra no grupo pertencente à rede social digital. $\mathrm{Na}$ busca por compreender, explicar e descrever esse tipo de análise, o estudo de caso por ser caráter singular, particular permite-nos desenvolver um maior aprofundamento em nosso objeto de estudo, como por exemplo: a interpretação em contexto, a retratação de uma realidade de forma mais completa e a variedade de informações. A partir da sistematização qualitativa das mensagens encontradas no conteúdo das websérie documental A short history of the Highrise (Uma breve história do Highrise), é que será possível a percepção do impacto que esse audiovisual 
na Era da Internet vem modificando e transformando não apenas o modo do fazer jornalístico, mas também, no aumento do índice de audiência que as webséries visam obter com esse novo público.

\section{Resultados}

A websérie documental A short history of the Highrise é dividida em quatro partes em que explica como o processo de verticalização foi sendo construído ao longo da história. A partir de imagens fotográficas que constroem a narrativa, a websérie foi elaborada em duas versões: uma para a visualização comum, como todo conteúdo audiovisual sem grandes novidades, e outra, para estimular a interatividade a partir da visualização do mesmo conteúdo em tablets. O recurso utilizado para a interatividade encontra-se na perspectiva de obtenção de informações extras, detalhes e no próprio percurso que o espectador fará ao assistir o conteúdo.

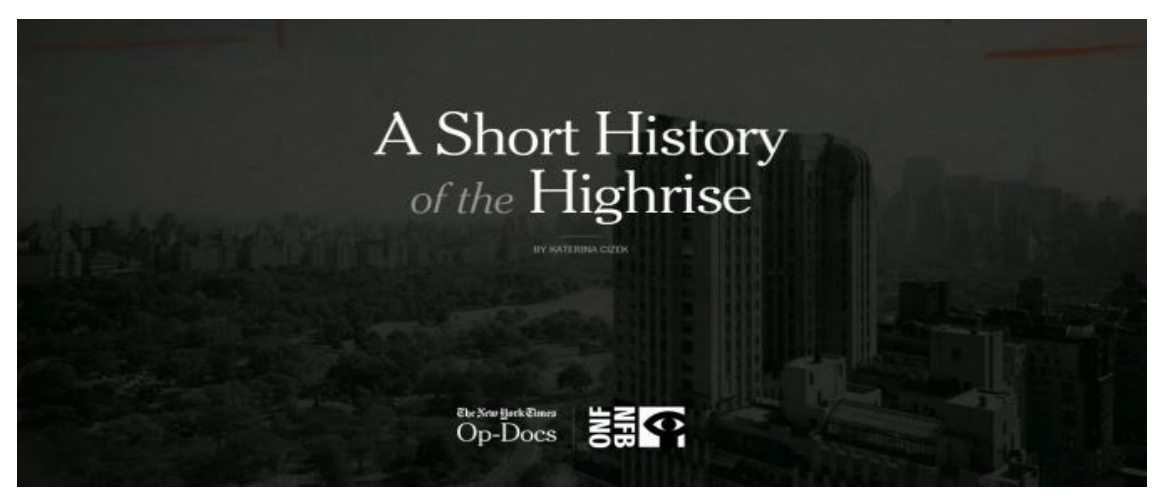

Figura 1: Abertura da websérie documental A short history of the Highrise 


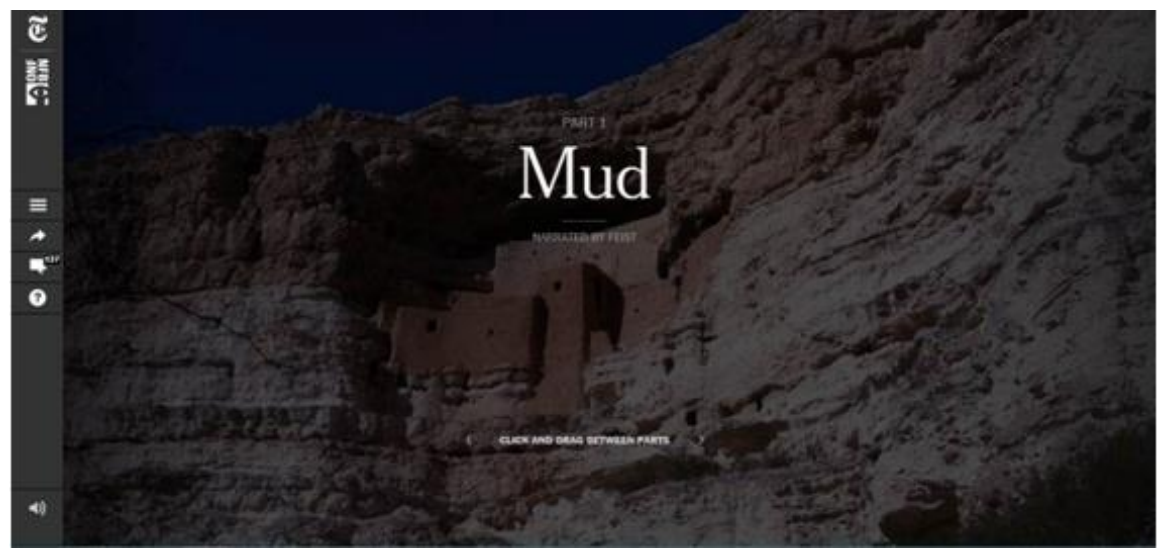

Figura 2: Parte 1 da websérie documental A short history of the Highrise

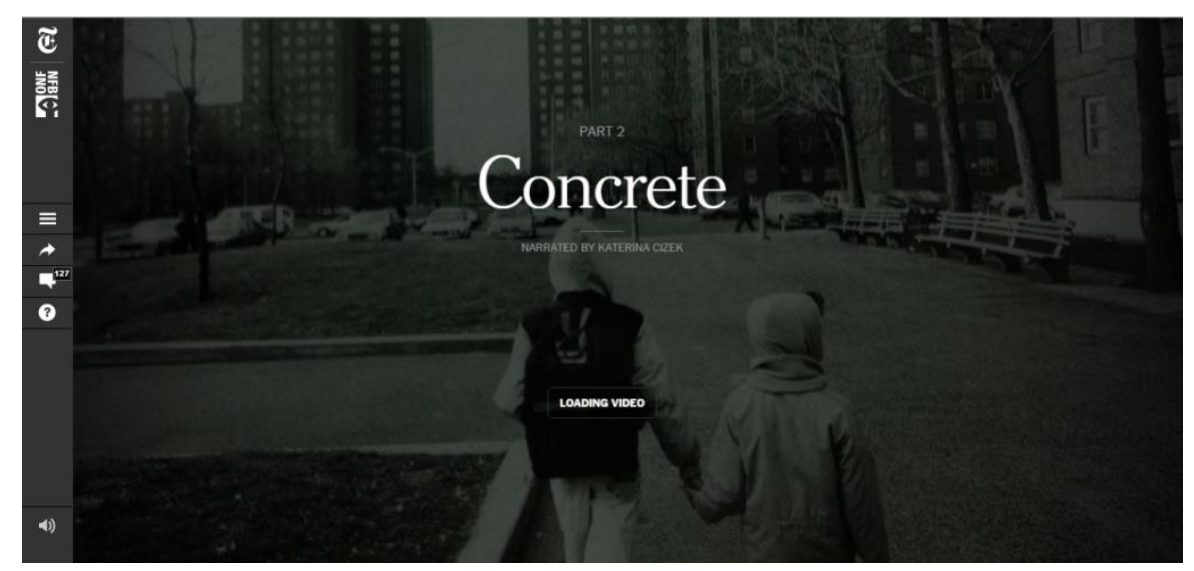

Figura 3: Parte 2 da websérie documental A short history of the Highrise

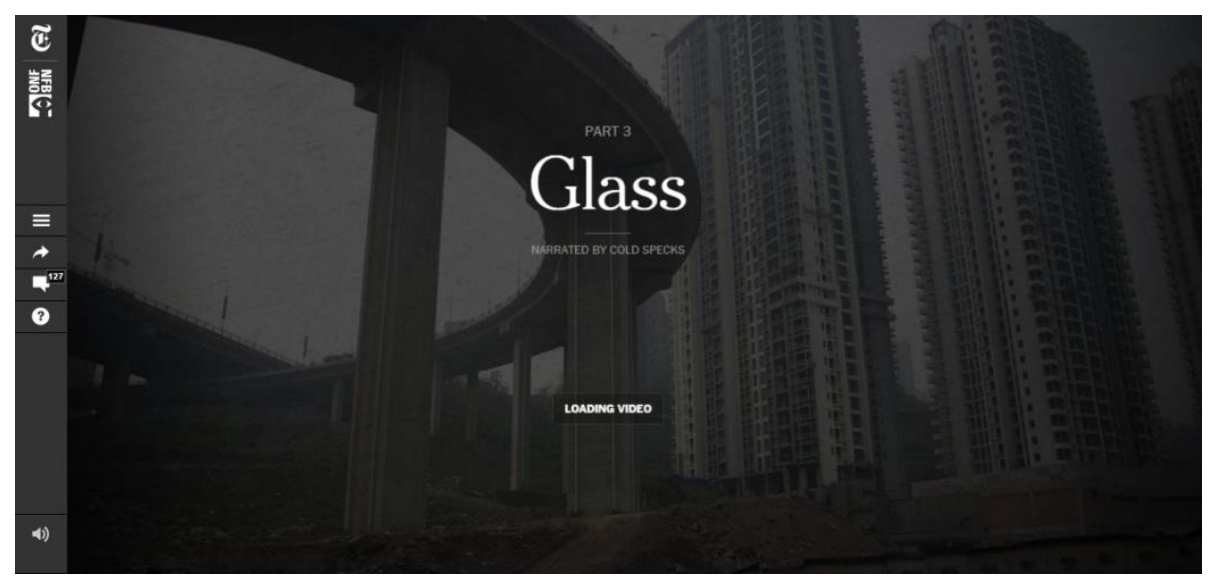

Figura 4: Parte 3 da websérie documental A short history of the Highrise 


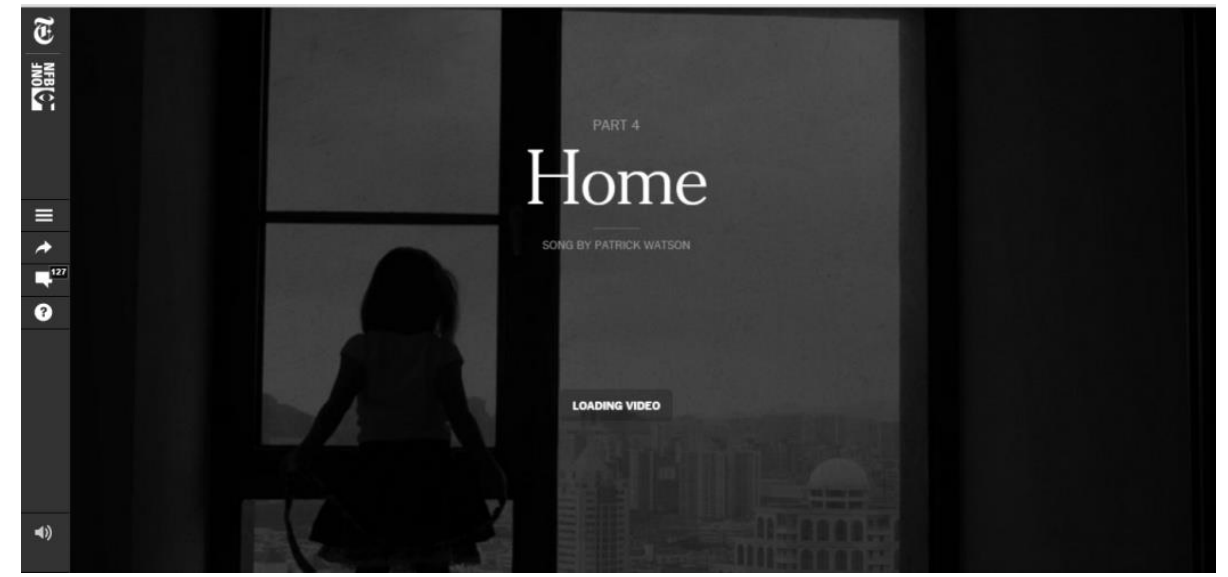

Figura 5: Parte 4 da websérie documental A short history of the Highrise

Uma experiência diferenciada pode ser analisada ao assistir o conteúdo através da plataforma digital pelo tablet. A narrativa construída com informações no verso das fotos, informações extras sobre determinada construção, época e local, nos permite identificar que a mensagem encontrada, no percurso feito pelo webespectador, a partir do conteúdo nem sempre será a mesma para cada indivíduo, e a compreensão desse conteúdo nos possibilita enxergar como a estrutura dessa nova produção digital funciona: "a análise de conteúdo tenta compreender os jogadores ou o ambiente do jogo num momento determinado, com o contributo das partes observáveis" (Bardin, 1977: 43). Essa compreensão proposta por Laurence Bardin determina como a aplicação da análise de conteúdo situa-se no estudo de caso dessas webséries específicas. 


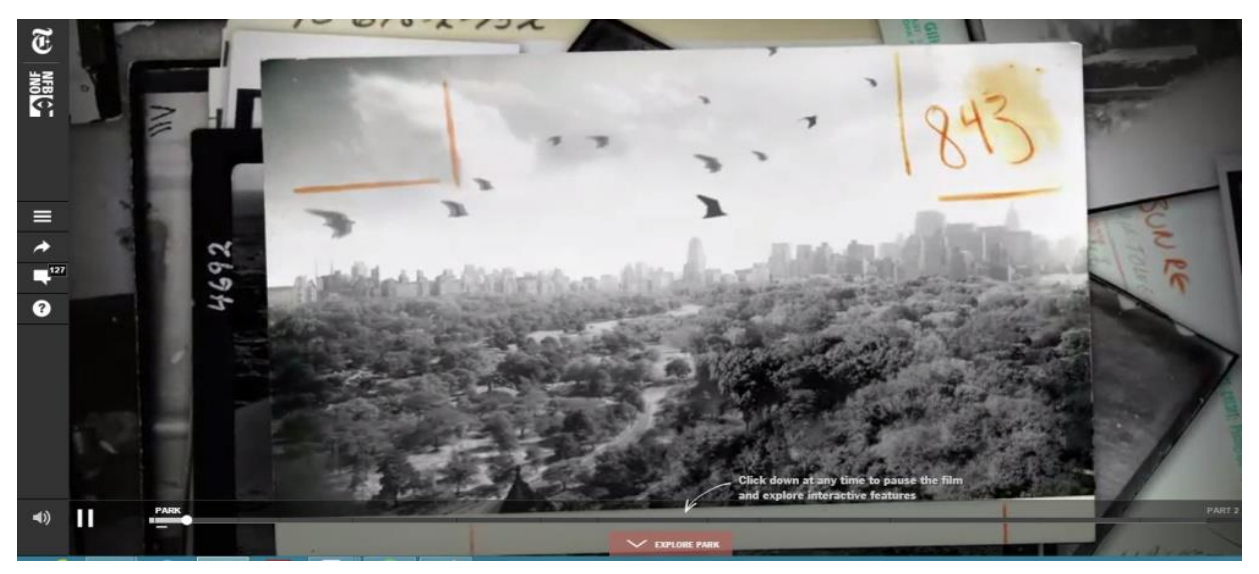

Figura 6: Trecho da parte 2 da websérie documental A short history of the Highrise

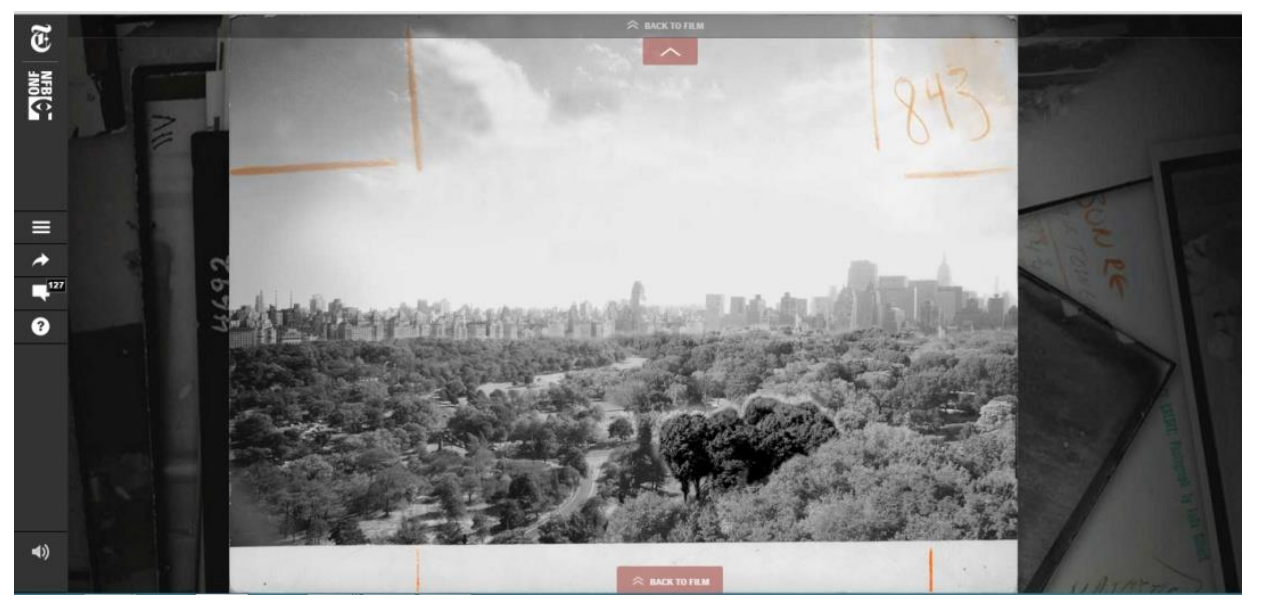

Figura 7: Trecho da parte 2 da websérie documental A short history of the Highrise em que explora a interatividade 


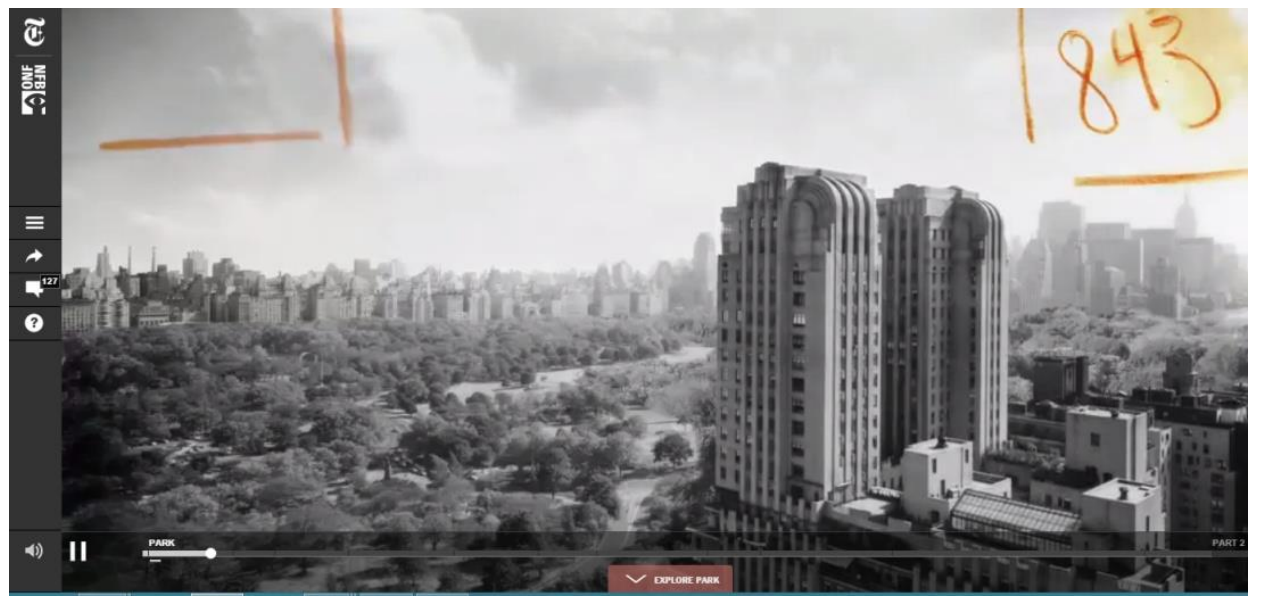

Figura 8: Trecho da parte 2 da websérie documental A short history of the Highrise em que explora a interatividade e as informações extras

A interatividade é um dos fatores mais importantes nesse processo de produção da websérie escolhida. Em conjunto com o conceito de tactilidade explorado por Marcos Palacios e Rodrigo Cunha (2012: 668) como mais uma das características do webjornalismo e que "antes ligada apenas a recursos de acessibilidade para deficientes visuais, tornou-se elemento essencial na comunicação em dispositivos móveis com tela sensível ai toque". Essa nova característica que permeia a produção dos conteúdos audiovisuais altera até então a relação prévia que se tinha estabelecido. Os dispositivos móveis propiciam novas experiências de contato.

Nas figuras acima (6, 7 e 8) podemos identificar como a interação permeia a produção desse conteúdo e sua relação com o webespectador. Os retângulos em vermelho com as indicações de setas representam os caminhos para as informações extras sobre a fotografia que aparece. Esses fluxos a mais (re) configuram o trajeto pré-estabelecido e proporcionam leituras e experiências diferentes para cada webespectador. Leituras que já são pré-definidas pelos produtores dos conteúdos dentre as " $\mathrm{x}$ " formas que 
são possíveis de acompanhar a visualização desta websérie. A interatividade neste sentido dá uma sensação de liberdade, mas que pode ser encarada como uma espécie de falsidade em sua estrutura, pois está, ao contrário, ainda no controle e na manipulação. A interatividade se encontra na possibilidade de acompanhar este conteúdo na hora em que o espectador desejar, pausando quantas vezes desejar e retrocedendo para visualizar algum detalhe ou se ater a uma informação com mais precisão.

Na significação da análise desse conteúdo não são as palavras, na forma escrita, que estão em jogo, mas as palavras em forma de visualidade. É a visualidade dessa narrativa interativa que perpassa entre um conteúdo noticioso e jornalístico, e outro, de diversão e de entretenimento. Esse infotenimento com características de interatividade, intrínseco ao conteúdo digital, confere a websérie documental como um dos produtos multimídias que adquirem cada vez mais espaço no cotidiano da sociedade. A relativa temporalidade de produção, circulação e distribuição, a fragmentação do conteúdo sem uma relação direta com as outras partes e a possibilidade de "manipulação" são itens que merecem total atenção das webséries. Esse conjunto de características corrobora para um aprofundamento das questões pertinentes a interatividade.

A websérie documental A short history of the Highrise tem em seu conteúdo uma proposta que permeia o jornalismo e o entretenimento. A crescente percepção desse recurso aplicado as empresas de comunicação tem sido conferido, nos últimos tempos, como uma tentativa de abarcar uma nova audiência para outro público além do já existente. Esse formato de audiovisual tem sido apropriado pelo webjornalismo, principalmente após a discussão sobre convergência das mídias e pelo desenvolvimento tecnológico das ferramentas disponibilizadas na Web. Essa mudança de movimentação das mídias e dos conteúdos é um dos interesses de aplicação da análise de conteúdo, e nas webséries não reside apenas na descrição dos conteúdos, mas no que eles podem trazer depois de serem tratados. 


\section{Considerações finais}

A escolha por tratar especificamente da websérie documental "A short history of the Highrise" deu-se, primeiramente, pelo objeto de estudo que visa a compreender o conteúdo de uma websérie documental. Em segundo, a partir do período de observação, durante 2 semanas entre os dias 3 a 17 de maio de 2015, porque nos foi possível constatar que pela utilização da narrativa fragmentada, hipertextual, interativa e multimídia poderíamos compreender as hipóteses que previamente estabelecemos como, por exemplo, a relação de participação que se altera a partir desse conteúdo interativo com o espectador.

O aumento significativo das produções, em larga escala, das webséries documentais perpassa a mídia digital e a relação multimidiática, que essa produção é modificada e alterada com esse tipo de conteúdo especializado para a Web, estabelecendo a participação do público diretamente no sentido da narrativa da websérie. Sendo considerado um item indispensável na construção da narrativa das webséries documentais, a interatividade surge como uma espécie de entretenimento, que busca atrair esse novo público (público que não mais apenas busca receber um conteúdo, mas que busca manipulá-lo, interagir com eles das mais variadas formas possíveis, ainda que não seja com uma total liberdade), e nas possibilidades de navegabilidade, como é demonstrada no estudo de caso escolhido acima, e que modifica a medição da audiência tradicional.

A navegabilidade está relacionada com as formas que cada indivíduo pode controlar sua forma de assistir, por exemplo. O conteúdo aqui pode ser acessado tanto pelo PC (Computador Pessoal), notebook, como pelos dispositivos móveis. A experiência de controle sobre pausar, retroceder ou avançar não está mais diante do poderio do produtor, mas dos próprios 
consumidores que decidem o que vão assistir, quando, como, onde vão acompanhar esse novo audiovisual.

A observação, a partir desse estudo de caso, nos demonstra que as webséries documentais estão se adaptando a nova realidade midiática. O amplo cenário da mídia digital ultrapassou as fronteiras que distanciavam produtores e consumidores, obra e espectador, e foi além dos tradicionais processos interativos que as mídias tradicionais disponibilizam em suas plataformas. A TV é um bom exemplo para que possamos compreender o processo de interatividade que até então se tinha estabelecido na sociedade. Era, e de certo modo permanece, um processo hierárquico em que os grandes conglomerados de comunicação detinham todos os poderes centralizados e propunham aos seus espectadores que participassem, mas sob as suas condições. Os produtos audiovisuais na Internet, ainda mantêm certo parâmetro com esses antigos meios, mas o avanço tecnológico possibilita que o "controle remoto" pausar, retroceder e avançar esteja nas mãos dos espectadores, e com isso a interação aconteça a partir da relação que cada indivíduo constrói com o objeto.

Esse processo que se apresenta junto a convergência midiática digital é fundamental para que uma participação e desenvolvimento de conteúdos participativos se encontrem cada vez mais permeados na vida social e cotidiana na contemporaneidade. Os documentários que passaram as fronteiras do cinema e da televisão e chegam ao espaço digital com uma proposta interativa, deixam visível a forte tendência que adentra o campo jornalístico no século XXI, com o desenvolvimento de novas ferramentas. Não é uma questão apenas tecnológica, de suportes e plataformas por onde permeiam os conteúdos. A relação de produção tem sido transformada com a realidade midiática que presenciamos. Os conteúdos são produzidos e pensados para as múltiplas telas, e não apenas para determinado suporte. É um caminho que vem sendo percorrido e que já encontramos, por exemplo, no audiovisual produzido pro empresas como a Netflix. Conteúdos 
audiovisuais para a Internet que estão sujeitos a se adaptarem para as mais diversas telas (TV, computador, smartphone e tablet).

É um caminho ainda sendo percorrido e adaptado, compreendido por ambos os lados (produtores e consumidores), e que necessita de uma maior exploração enquanto pesquisa para perceber os avanços e as transformações que esses conteúdos carregam consigo. Uma vez que a narrativa vai sendo alterada de acordo com o fluxo de navegação individual, e que não pode ser mais determinado ou pré-estabelecido pelo produtor. Essa relação narrativa concentra-se apenas no conteúdo e no seu espectador/usuário. Desconstruindo ou não a narrativa, seguindo ou modificando as passagens que busca assistir e criando novas formas de enredo para o conteúdo que está sendo manipulado.

\section{Referências bibliográficas}

AERAPHE, Guto (2013), Webséries: criação e desenvolvimento, Rio de Janeiro: Ed. Ciência Moderna Ltda.

BARDIN, Laurence (1977), Análise de conteúdo, Tradução de Luís Antero Neto e Augusto Pinheiro, São Paulo - Ed. Editora 70.

BAUER, Marcelo (2011), Os webdocumentários e as novas possibilidades da narrativa documental, Cross Content, Brasil.

BRADSHAW, Paul (2014), "Instantaneidade: efeitos da rede, jornalistas móbile, consumidores ligados e o impacto no consumo, produção e distribuição" in CANAVILHAS, João (Org.), Webjornalismo: 7 características que marcam a diferença, Covilhã, Portugal: UBI/ LabCom.IFP, Livros LabCom.

CAJAZEIRA, Paulo Eduardo (2014), A audiência convergida do telejornal nas Redes Sociais. Tese de Pós-doutorado, Laboratório de 
Comunicação Online do Programa de PósGraduação em Ciências da Comunicação (Universidade da Beira Interior/LabCom.IFP/ Portugal) sob a supervisão do Professor António Fidalgo.

CANAVILHAS, João (2014), "Hipertextualidade: Novas arquiteturas noticiosas" in CANAVILHAS, João (Org.), Webjornalismo: 7 características que marcam a diferença, Covilhã, Portugal: UBI/ LabCom.IFP, Livros LabCom.

CANCLINI, Néstor García (2008), Leitores, espectadores e internautas, Tradução Ana Goldberger, São Paulo: Iluminuras.

CROU, Oliver (2010), Qu'est-ce que le webdocumentaire?, WEBDOCU.fr. CUNHA, Ricardo; PALACIOS, Marcos (2012), A tactilidade em dispositivos móveis: primeiras reflexões e ensaios de tipologia. Contemporânea - Comunicação e Cultura - vol. 10, n. 03, pp. 668685. Salvador, Brasil - UFBA.

DAYAN, D. (2006), Televisão, o quase público. Lisboa: Livros Horizonte.

DEJAVITE, Fábia Angélica (2006), Infotenimento: informação mais entretenimento no jornalismo, São Paulo: Ed. Paulinas.

GERHARDT, Tatiana Engel; SILVEIRA, Denise Tolfo (2009), Métodos de pesquisa, Universidade Aberta do Brasil - UAB/UFRGS e pelo Curso de Graduação Tecnológica - Porto Alegre: Editora UFRGS.

JENKINS, Henry (2009), Cultura da convergência, Tradução Susana Alexandria, $2^{a}$ Ed., São Paulo: Aleph.

LÉVY, Pierre (2014), A inteligência coletiva: por uma antropologia do ciberespaço, Tradução Paulo Rouanet, $9^{a}$ Ed., São Paulo: Edições Loyola.

PEREIRA, Marcos José (2011), Sistemas multimídia in DURÃO, Paulo Carlos Pires da Costa; MANDARINO, Denis Garcia (Org.), Novas interfaces em comunicação e audiovisual: mudanças no pensamento cotidiano, São Paulo: Lexia. 
PRIMO, Alex, (2007), Interação mediada por computador: comunicação, cibercultura, cognição, Porto Alegre: Sulina.

RITTER, Raquel Longhi (2014), O audiovisual como gênero expressivo e sua reconfiguração no jornalismo online, Revista Estudos da comunicação, nº 16, p. 69-88, junho.

ROSSINI, Miriam de Souza (2009), Traduções audiovisuais: múltiplos contatos entre cinema e tevê. In: ROSSINI, Miriam de Souza; SILVA, Alexandre Rocha da (Org.), Do audiovisual às audiovisualidades - convergência e dispersão nas mídias, Porto Alegre, RS: Asterisco.

ROST, Alejandro (2014), "Interatividade: definições, estudos e tendências" in CANAVILHAS, João (Org.), Webjornalismo: 7 características que marcam a diferença, Covilhã, Portugal: UBI/ LabCom.IFP, Livros LabCom.

SALAVERRÍA, Ramón (2014), "Multimedialidade: Informar para 5 sentidos", in CANAVILHAS, João (Org.), Webjornalismo: 7 características que marcam a diferença, Covilhã, Portugal: UBI/ LabCom.IFP, Livros LabCom.

SILVA, Carla Pollake (2006), Estudos de Audiência e Recepção: mais do que números do Ibope - aspectos históricos, Sociedade Brasileira de Estudos Interdisciplinares da Comunicação XXIX Congresso Brasileiro de Ciências da Comunicação, UnB, 6 a 9 de setembro, pp. 1-17.

TEMER, Ana Carolina Rocha Pêssoa (2014), Desconstruindo o telejornal: um método para ver além da mélange informativa. In. COUTINHO, Iluska; MELlO, Edna; PORCELlO, Flávio; VIZEU, Alfredo (Org.) Telejornalismo em questão, Coleção Jornalismo Audiovisual, V. 3. Florianópolis, Insular. 